Ma, “Canada's Façade of Equality" 11

\title{
Canada's Façade of Equality: Austin Clarke's More
}

\author{
Mary Ma
}

Canada is known as a haven for immigrants. Canadian migrants, their children, and their grandchildren live in the diaspora, a physical community who "acknowledge that "the old country' [...] always has some claim on their loyalty and emotions" (Cohen qtd. McLeod 237) and carry a fractured sense of identity through "living in one country but looking across time and space to another" (McLeod 237). Canada prides itself as a multicultural nation that champions inclusivity, diversity, and equality. However, it seems Canada's often glorified multiculturalism is little more than "a media mask, [...] a public advertising campaign" (McLeod 262). This façade seems to be promoted by Canadian media, government, and society to perpetuate an illusion of equality while concurrently "ignor[ing] the underlying and continuing inequalities and prejudices that blight the lives of diasporic peoples" (McLeod 262). In the novel More, Austin Clarke incisively exposes the implicit systemic and societal racism festering in Canada, while also exposing the psychological complexities of living in the diaspora.

In More, Clarke unmasks Canada's systemic discrimination which has long allowed Canadian employers to retain power while subjugating vulnerable immigrant workers. Clarke delineates this systemic racism by describing the limited employment opportunities immigrants, especially Black immigrants, have in Canada. In the novel, Bertram is an apprentice mechanic in Barbados. Upon his arrival in Canada, he earnestly pursues a job in his specialized field. However, "after two months of single-minded perusal of the pages that advertised hundreds of jobs, skilled and unskilled, that related to repairing cars" (Clarke 67), Bertram abandons his dream. For the remainder of the narrative, he holds a number of low wage temporary jobs, capitulating to a system designed to keep him at the bottom. Canadian employers were unwilling to recognize Bertram's credentials and train him to complete his apprenticeship. The lack of opportunity dooms Bertram, a qualified immigrant, to poverty without means to achieve economic security simply because his training was foreign.

Bertram's plight in More reflects the current struggle of recent, skilled immigrants unable to obtain Canadian jobs in their desired fields for which they have the necessary training, education, and experience. Canada's current immigration policy is designed to admit skilled immigrants and "to attract highly skilled workers with advanced educational credentials and professional experience to best address Canada's economic needs" (Kaushik and Drolet 2). However, despite their qualifications and experience, skilled immigrants experience high levels of unemployment and underemployment (Kaushik and Drolet 4). As stated in the Ontario Human Rights Commission's Policy on Removing the "Canadian experience" barrier, "even after being in Canada for fifteen years, "immigrants with a university degree are still more likely than the native-born to be in low-skilled jobs." A significant factor of this unemployment and underemployment is the discrimination of Canadian employers. It is known that the: "barriers to employment include a lack of recognition of foreign credentials, lack of recognition of previous work experience or employers' requirement for Canadian experience, difficulties in obtaining references, and discrimination" (Kaushik and Drolet 4).

Skilled immigrants "experience significant downgrading of their foreign credentials in Canada" (Kaushik and Drolet 5). This devaluing of qualifications by Canadian employers affects all areas of employment in Canada: "the downgrading of foreign credentials does not stop at highly regulated professions, such as physicians, engineers, teachers, social workers, but it also takes place in unregulated professions" (Kaushik and Drolet 5). Furthermore, skilled immigrants 
of visible ethnicities face the added barrier of credential devaluation simply because of Canadian employers' racism (Kaushik and Drolet 5). Skilled non-White immigrants "suffer [a] significant disadvantage in receiving callbacks for interviews compared with white natives with similar job relevant characteristics" (Quillian et al. 486). In Canada, the majority of the Black community are "immigrants who entered Canada after 1960, and their descendants" (Attewell et al. 475) due to "Canadian immigration policy chang[ing] to allow large numbers of non-Europeans to immigrate" (Attewell et al. 475). However, the overwhelming majority of Black Canadians face not only the systemic discrimination of Canadian employers but also the pervasive, lasting, and overwhelming economic and psychological damages of systemic inequality.

The argument used to justify Canadian employers' gatekeeping is that Canada has a right to protect Canadians. However, through this logic, Canada becomes not a land of equal opportunity, but one that deceives immigrants by advertising itself as such. Clarke has explored this hypocrisy in other works such as his short story "Canadian Experience." In More and "Canadian Experience," Clarke "suggests that one's ability to perform skilled work or otherwise contribute to Canadian society can be severely undercut simply because one does not possess "Canadian Experience"' (Chariandy 146). Immigrants or those who live in the diaspora have no means of gaining this experience because Canadian employers will not hire or train them. Furthermore, the process of credential recognition for skilled immigrants is "lengthy, timeconsuming, and expensive" (Kaushik and Drolet 5), and if their training is not recognized immigrants are forced to restart training or education altogether (Kaushik and Drolet 5).

Immigrants who do not have the economic means or are psychologically broken by the system, like the character Bertram in Clarke's novel, may never gain the opportunity to work in their desired field and subsequently work in positions for which they are overqualified. Through this discrimination, Canadian employers exclude immigrants from employment, belonging, and dignity, while the Canadian government continues to target skilled immigrants with the lure of promised equal opportunity. It is fundamentally exploitative of the Canadian government to bait skilled immigrants with the promise of equality and a multicultural society while masking the discriminatory reality that Canadian employers' racism and prejudice keep immigrants in low paying jobs.

Education is another tool used to oppress those living in the diaspora. Education is inseparable from employment, and employment is inseparable from power or personal autonomy. In Clarke's novel, Idora comes to Canada from Barbados to live a better life: "[s]he had always wanted to go to Canada, to continue her education, go to university, and take a degree in English Literature of the Victorian Era, and become a teacher" (Clarke 68). Poverty and systemic discrimination prevent Idora's dream from ever being realized. Idora's responsibility as the economic provider for her family coupled with her low income and debt impede her economic and social mobility as university is expensive and time-consuming. Thus, Idora is never able to pursue her dreams or rise from her poverty and debt through higher-paying employment. Clarke symbolizes this at the beginning of the novel when she wakes from her dream full of wonder and hope, only to be confronted by the sight of black tree limbs "dead now on the thin layer of snow that whitens the ground in these cold, teeth-shattering mornings of winter" (Clarke 1). As Barrett writes, "if the dream at the beginning of the narrative is the migrant's dream of reinvention and a new life in a new country, that dream of reinvention is denied at the very outset of the text" (76). Barrett asserts that Idora's dream of a better life in Canada is shattered by "the reality of black abjection from the Canadian body politic and black social immobility within Canada” (76). Idora's immobility portrays the consequences of 
systemic Canadian discrimination, especially for Black Canadians. Both generational and immigrant Black Canadians earn less than their White Canadian counterparts: "compared to Canadian whites, both black immigrants and native-born black males suffered an earnings disadvantage" (Attewell et al. 477). This lack of financial earnings adds to almost insurmountable barriers faced by Black Canadians to free themselves from destitution. Furthermore, currently, there are no laws to regulate parity in education in Canada. The Canadian government's diversity legislation, the Employment Equity Act, does not apply or regulate education and has only been reviewed once in 1995 (Collie). This gap in federal action has perpetuated education practices that disproportionally affect Black Canadians such as streaming. Streaming students into either applied or academic tracks disproportionally affects Black students, creating another barrier towards further education and is only now being phased out in Ontario (CBC News).

Furthermore, systemic racism in Canada is enforced by racism unaddressed within the police force. In his novel, Clarke exposes the brutal prejudice rampant in Canadian law enforcement through the murder of BJ by a racist police officer. A White police officer, Brandon, and his partner senselessly murder BJ, Idora's son (Clarke 239), and plan to cover up this racist act using an invented crime based on stereotypes that Black men are degenerate, poor, and violent. BJ was murdered for trying to return to his home, and for being a Black man in Canada in the wrong place at the wrong time. Idora loses her son to a senseless homicide because of unacknowledged racism in Canadian society. Clarke foreshadows BJ's murder by police stating that: "[ $\mathrm{t}]$ he boys, the black boys, are always the targets of the blasted system. [...] They are always killing-off our black sons" (219). Idora is aware of this systemic criminal profiling, stating, "[c]ould you tell me what do the police of this city have against Jamaicans? Profiling them so?" (Clarke 97). Criminal profiling in Canada means that "Black people in Canada are subject to invasive police surveillance that makes it difficult to exist in public space" (Maynard 83). It is also known that Black Canadians are "more likely to be stopped and questioned" (Maynard 83) and "to be charged, severely sentenced and incarcerated in jails or prisons, and are less likely to be granted parole" (Maynard 83). One of the main motivations for this excessive surveillance and arrests may be the false and prejudiced belief of police officers who already consider Black Canadians criminals ( A Disparate Impact 2). This belief is exemplified by the evidence presented that "Black people represented 35.2\% of people involved in "out-of-sight" driving charges (such as driving without valid insurance), which are charges that only arise after a stop has already taken place, suggesting other motives for the stop" (A Disparate Impact 2). Moreover, Black Canadians are "more likely to be struck, shot or killed by the Toronto police" (A Disparate Impact 2). In terms of fatal shootings, Black Canadians are disproportionately killed by police shootings: "[b] etween 2013 and 2017, a Black person in Toronto was nearly 20 times more likely than a White person to be involved in a fatal shooting by the Toronto Police Service" (A Collective Impact 3). If Canada were a nation free from racial prejudice, Black Canadians would not have to fear police brutality unchecked by the Canadian government and further systemic prejudice by the Canadian judicial system and prisons.

In Canadian society, police officers and the justice system represent equality, authority, and the moral fabric of Canada. Law enforcement also represents power and social control. As police are humans influenced by prevailing "social values, including biases related to socially constructed boundaries such as race" (Smith 57), their actions are subjective though they represent objective equality and justice. Therefore, police racism and brutality must be uprooted, prevented, and condemned. However, fatal use of force by police is quite often not prosecuted: 
"[o]ver 17 years and 52 incidents, just seven Toronto Police officers have faced charges after being involved in the death of a civilian" (Dunn). Of these fifty-two fatalities, nineteen victims were Black men (Dunn), more than any other ethnic group despite Black people only making up little more than eight percent of the population (Dunn). Moreover, Canada does not have an "official national record of the number of people killed during encounters with police" (Simpson), and the irregular reports released from individual police departments are "not collected based on race, ethnicity or other critical factors" (Simpson). Clarke exposes this lack of accountability through the media's official description of Albert Johnson's death at the hands of police officers: "The Star gave no motive, and not much more information" (Clarke 95). This lack of information contributes to the absence of accountability for racially motivated police brutality. Moreover, in some cases, the officers who kill or injure Canadians are not even made known to the public, the family, or the victim. Such was the case for the family of James Butler who was shot five times by RCMP Sergeant Everett McLachlan (DeRosa). The family did not even learn the name of the officer who killed Butler until four years after the incident, as he was not named in the report which exonerated McLachlan (DeRosa). This incident is an example of the lack of transparency regarding Canadian law enforcements' use of force: 'it's nearly impossible to track an officer's discipline record or use-of-force history except for rare instances where criminal charges are laid" (DeRosa). Even if officers are charged, they may be allowed to return to active duty, as was the case when "Const. Josh Grafton, Const. Wayne Connell and Const. Kyle Sharpe, were charged in connection with a violent arrest" (DeRosa), but subsequently returned to active duty (DeRosa). This absence of information, prosecution, and ramifications regarding police officers' use of force creates a pre-existing environment where racist police do not fear consequences or discipline for their actions.

Furthermore, the scarcity of transparency and repercussions often means that prejudiced police officers are faced with no apparent consequences for their brutal or fatal actions. As a result, racist police officers may feel that they are not only free to continue their racist violence, but also may become glided in a sense of invincibility, unfounded heroism, and distorted justice. Clarke uses his description of Brandon in the novel to portray the dangerous distortion bred from this lack of correction: "[y]ou look at a kid like that, $[\ldots]$ and you feel that if you don't do something to him, the next time you see him again, he will either be robbing a convenience store or shooting innocent teenage girls out shopping" (Clarke 213). When Brandon and his partner murder BI, they are confident that they will face no repercussions for their actions, if they are able to say the right words. Their dialogue reveals this, as one asks, "[w] hat are we going to write this up as, in our report?" (Clark 238), the other replies "[w] hat the fuck does it matter, in this community?" (Clarke 238), and they conclude "[1]et's just put down common assault, with intent" (Clarke 239). Unchecked police brutality in Canada perpetuates a sense of mortal danger and a palpable, pervasive, constant fear of safety for Black Canadians. Black Canadians live intimately with the danger of injury or murder by racist police uninhibited by a complicit system: "[t]o be Black is not only to be targeted for questioning or arrest, it is also to be "proximate to death"' (Maynard 84). Therefore, they are not able to belong to Canadian society when its rule of law is thus corrupted and complicit in the brutal, racist psychological and physical violence inflicted upon Black Canadians.

Canadian societal prejudice is also manifested in the way the media talks about Black immigrants and especially Black men, spitefully asking "[w] here are the Men?" (Clarke 40), implicitly describing Black men to be degenerate and Black women to being unable to retain their partners. Canadian media in the past and present perpetuates "the ever-unsubstantiated 
association of Blackness with immorality, depraved sexuality and criminality" (Maynard 41). Clarke specifically designs Josephine, Idora's White Canadian friend, to be a manifestation of Canada's façade of multiculturalism. Josephine commits multiple acts of epistemic violence towards Idora in the novel, mocking fundamental symbols of Idora's personal and ethnic identity. When Idora exclaims she misses "pig tails and salt fish" (Clarke 195), Josephine grimaces in disgust. Idora replies, "[y]ou don't like my name [...] and you don't like my food" (Clarke 195). Clarke describes the inseparability of Josephine and Brandon, the racist police officer: "Josephine was living inside Brandon's words now, as if his words were her words; as though it was her story too" (Clarke 213). Because Josephine is not only shielding Brandon but also continuing a romantic relationship with him, she is directly allowing horrific police brutality and injury to Canadians of visible ethnicities. Josephine values her relationship with Brandon over justice or morality. Josephine is aware of the monstrous deeds Brandon has committed, but she is willing to turn a blind eye to his racist, violent, and horrific actions. Though she shrouds herself with a façade of acceptance and inclusion towards Canadians of visible ethnic backgrounds, Josephine is a selfish, privileged hypocrite. Clarke seems to suggest that Josephine is representative of the typical Canadian liberal or moderate. Furthermore, through this pairing of Josephine and Brandon, Clarke delineates the implicit, psychological violence and the systemic, brutal violence faced by Black Canadians.

The insidious, surrounding prejudice of Canadian society pressures Idora to further internalize a sense of inferiority and isolation- both psychological injuries she is vulnerable to because of the fractured loneliness of living in Toronto. Idora is an intensely lonely woman. Making a new life in a new country is already fraught with anguish and grief, but with the added stress of constant discrimination and threatened safety, it becomes almost unbearable. Idora is alienated in Canada; she is, as Barrett writes, "relegated to a marginal space" (77). Clarke tracks Idora's movements in Toronto and the silent prejudice she faces on her forays into Canadian society. As Barrett writes, "[t]he precision with which Clarke maps out Idora's movement demonstrates the traces that black bodies leave in the city through which they often move alone, unwanted, and unnoticed" (Barrett 77). Idora is aware of the invisible barriers surrounding her: "[s]he is the only black person in this coach of the subway. 'This feeling of being in the minority... of inferiority... not that I am inferior... this feeling of segregation runs through my mind, each time I travel on public transportation"' (Clarke 69). This isolation causes her to further negatively internalize her ethnicity: "I should know better, an educated woman like me. But it... this thing... takes away your better judgement, and makes you believe you're what they paint you and define you to be" (Clarke 69). Idora longs to be accepted into Canadian society; she abhors the term "visible minority" because it automatically others her. However, Canada constantly marginalizes Idora and discriminates against her because of her ethnicity. How can she build a home when she is so psychologically abused? Moreover, since the media portrays and dooms Black Canadians to either criminal or victim identities, Idora is both painfully visible and invisible to Canadian society:

Her invisible visibility made her seethe with anger and rage for the police and for white people, but it also made her feel guilty, inferior, sorry to be so visible and to have her situation so often smeared in big headlines and colour photographs on the front pages of the Star. (Clarke 109-110)

Before Canada can call itself a multicultural nation, it must allow Black Canadians belonging and safety instead of its current dismissive hostility: "black Canadians have historically asserted a Canadian national belonging, but their claims of national belonging have 
to be seriously recognized before they are treated as significant — not marginal — national community members" (Green 3). All Black Canadians, whether they be generational Canadians or recent immigrants, must be allowed to belong to Canadian society and therefore must not be forced into assuming dichotomous identities of either invisible, powerless victims or visible, degenerate criminals. These identities imposed upon Black Canadians exclude them from dignity, safety, and community.

In his novel More, Austin Clarke lays bare Canada's hypocritical multicultural façade by exposing systemic, societal, insidious racism in Canada experienced by many of those living in the diaspora, especially Black immigrants. Bertram, BJ, and Idora are broken by Canadian systems which deprive them of autonomy, safety, and belonging. Canadian employers use the trifecta of Canadian references, Canadian education, and Canadian experience to exploit immigrant workers, relegating them to unemployment and underemployment for the benefit of Canadian born citizens. Additionally, this systemic discrimination withholds economic opportunity for immigrants to elevate themselves from poverty, a reality mirrored in More by Idora's continued indigence despite her thirty years in Canada. Canadian media and supposedly accepting Canadians hypocritically proclaim equality but also continue to either slander Black Canadians or enable discrimination towards them. Furthermore, Canadian law enforcement and the justice system not only shield police officers' brutal violence or murder, but also contribute to the exclusion and danger felt by Black Canadians. Thus, Canada's systemic and societal prejudice prevents it from being a land of equal opportunity, and rather one which profits from the exploitation of those it claims to welcome: people living in the diaspora. Austin Clarke's novel is a searing indictment of Canada's often trumpeted multiculturalism. 


\section{Works Cited}

Attewell, Paul, et al. "Black Canadians and Black Americans: Racial Income Inequality in Comparative Perspective." Ethnic and Racial Studies, vol. 33, no. 3, Informa UK Limited, 2010, pp. 473-95.

https://librarysearch.mtroyal.ca/permalink/01MTROYAL_INST/1vb0hdi/cdi_crossref_ primary_10_1080_01419870903085883

Barrett, Paul. Blackening Canada: Diaspora, Race, Multiculturalism. University of Toronto Press, 2015.

https://librarysearch.mtroyal.ca/permalink/01MTROYAL_INST/1ktpanp/alma9917165 353404656

CBC News, "Ontario to end 'discriminatory' practice of academic streaming in Grade 9." $C B C$, 2020.

https://www.cbc.ca/news/canada/toronto/ontario-streaming-high-school-racism-lecce1.5638700

Chariandy, David. “'That's What You Want, Isn't It?': Austin Clarke and the New Politics of Recognition." Journal of West Indian Literature, vol. 14, no. 1/2, Department of Literatures in English, University of the West Indies, 2005, pp. 141-65.

https://ibrarysearch.mtroyal.ca/permalink/01MTROYAL_INST/jd01d7/jstor_archive_1 123020016

Clarke, Austin. More: A Novel. Thomas Allen Publishers, 2008.

Collie, Meghan. "Canada has a discrimination problem when it comes to hiring — here's why." $C B C, 2019$.

https://globalnews.ca/news/5424465/discriminatory-hiring-practices-canada/

DeRosa, Katie. "Four years later, family seeking police transparency learned name of officer who killed man.” Times Colonist, 2020.

https://www.timescolonist.com/news/local/four-years-later-family-seeking-policetransparency-learned-name-of-officer-who-killed-man-1.24157037

Dunn, Trevor. "In deadly encounters with Toronto police, more than a third of victims are black." $C B C, 2018$.

https://www.cbc.ca/news/canada/toronto/police-deaths-blacks-data-1.4599215

Green, Kim, et al. "To Be Black and 'at Home",: Movement, Freedom, and Belonging in African American and African Canadian Literatures. ProQuest Dissertations Publishing, 2010. http://search.proquest.com/docview/761355253/

Kaushik, Vibha, and Drolet, Julie. "Settlement and Integration Needs of Skilled Immigrants in Canada." Social Sciences, vol. 7, no. 5, 2018. 
https://librarysearch.mtroyal.ca/permalink/01MTROYAL_INST/1vb0hdi/cdi_doaj_prim ary_oai_doaj_org_article_ada42c32585d45c799b42fae7bffb496

Maynard, Robyn. Policing Black Lives: State Violence in Canada from Slavery to the Present. Fernwood Publishing, 2017.

McLeod, John. Beginning Postcolonialism. 2nd ed., Manchester University Press, 2010.

Ontario Human Rights Commission. A Collective Impact: Interim report on the inquiry into racial profiling and racial discrimination of Black persons by the Toronto Police Service. 2018.

http://www.ohrc.on.ca/sites/default/files/TPS\%20Inquiry_Interim\%20Report\%20EN\%2 0FINAL\%20DESIGNED\%20for\%20remed_3_0.pdf\#overlaycontext=en/news_centre/ohrc-interim-report-toronto-police-service-inquiry-showsdisturbing-results

Ontario Human Rights Commission. A Disparate Impact. 2020. http://s3.documentcloud.org/documents/7032588/OHRC-a-Disparate-Impact.pdf

Ontario Human Rights Commission. Policy on Removing the "Canadian experience" Barrier. 2013.

http://www.ohrc.on.ca/en/policy-removing-\%E2\%80\%9Ccanadianexperience $\% \mathrm{E} 2 \% 80 \% 9 \mathrm{D}-$ barrier

Quillian, Lincoln, et al. "Do Some Countries Discriminate More Than Others? Evidence from 97 Field Experiments of Racial Discrimination in Hiring." Sociological Science, vol. 6, no. 18, Society for Sociological Science, 2019, pp. 467-96.

https://www.sociologicalscience.com/articles-v6-18-467/

Simpson, Natasha. “Canada Has Race-Based Police Violence Too. We Don’t Know How Much." The Tyee, 2020.

https://thetyee.ca/Analysis/2020/06/02/Canada-Race-Based-Violence/

Smith, Charles C. "Racial Profiling in Canada, the United States, and the United Kingdom." Racial Profiling in Canada: Challenging the Myth of 'a Few Bad Apples', by Carol Tator et al., University of Toronto Press, 2006, pp. 55-91. 